\title{
Extratropical cyclones over the North Atlantic and western Europe during the Last Glacial Maximum and implications for proxy interpretation
}

\author{
Joaquim G. Pinto ${ }^{1, \star}$ and Patrick Ludwig ${ }^{1,}$ \\ ${ }^{1}$ Institute of Meteorology and Climate Research, Karlsruhe Institute of Technology, 76131 Karlsruhe, Germany \\ « These authors contributed equally to this work.
}

Correspondence: Joaquim G. Pinto (joaquim.pinto@kit.edu)

Received: 19 November 2019 - Discussion started: 2 December 2019

Revised: 20 February 2020 - Accepted: 1 March 2020 - Published: 1 April 2020

\begin{abstract}
Extratropical cyclones are a dominant feature of the midlatitudes, as their passage is associated with strong winds, precipitation and temperature changes. The statistics and characteristics of extratropical cyclones over the North Atlantic region exhibit some fundamental differences between pre-industrial (PI) and Last Glacial Maximum (LGM) climate conditions. Here, the statistics are analysed based on results of a tracking algorithm applied to global PI and LGM climate simulations. During the LGM, both the number and the intensity of detected cyclones were higher compared to PI. In particular, increased cyclone track activity is detected close to the Laurentide ice sheet and over central Europe. To determine changes in cyclone characteristics, the top 30 extreme storm events for PI and LGM have been simulated with a regional climate model and high resolution $(12.5 \mathrm{~km}$ grid spacing) over the eastern North Atlantic and western Europe. Results show that LGM extreme cyclones were characterised by weaker precipitation, enhanced frontal temperature gradients and stronger wind speeds than PI analogues. These results are in line with the view of a colder and drier Europe, characterised by little vegetation and affected by frequent dust storms, leading to reallocation and build-up of thick loess deposits in Europe.
\end{abstract}

\section{Introduction}

The day-to-day weather conditions in the midlatitudes are strongly affected by the passage of extratropical cyclones, which are typically associated with precipitation, strong winds and changes in temperature and cloudiness. Cyclones also play a major role in the water cycle and the redistribution of momentum and energy in the climate system (Hoskins and Valdez, 1990; Chang et al., 2002). The assessment of cyclone activity, notably to analyse their paths, characteristics and impacts, is thus key to determine the day-to-day weather conditions, the regional mean climate and its variability on multiple timescales. In fact, there is a wide range of literature analysing case studies of extreme cyclones (e.g. Wernli et al., 2002; Ludwig et al., 2015), the mean cyclone activity in the midlatitudes in the recent past (e.g. Hoskins and Hodges, 2002; Ulbrich et al., 2009) and possible changes under future climate conditions (e.g. Bengtsson et al., 2009; Ulbrich et al., 2009). On the other hand, studies analysing the structural characteristics of extratropical storms from a climatological perspective are less frequent (e.g. Catto et al., 2010; Rudeva and Gulev, 2011; Dacre et al., 2012; Hewson and Neu, 2015; Sinclair et al., 2020). While some general concepts are available on how warmer climate conditions will affect the intensity and structure of cyclones, there are still several open questions, particularly regarding how dominant the increased latent heating may become compared to other physical processes like low-level and upper-level baroclinicity (see Catto et al., 2019; their Fig. 2).

The availability of studies addressing the characteristics of cyclone activity outside of the period extending from the mid-19th century to the end of the 21 st century decreases sharply. Raible et al. (2018) analysed variations of cyclone statistics in a very long simulation with a fully coupled Earth system model from 850 to $2100 \mathrm{CE}$. While they identified 
variations on multiple timescales, they found no evidence for an external forcing imprint before 1850. Moreover, Pfahl et al. (2015) analysed cyclone activity in idealised aquaplanet simulations covering a wide range of possible climate conditions (from 270 to $316 \mathrm{~K}$ global mean temperatures). While the structure of the majority of the cyclones reveals only small changes on average, larger differences were identified for intense cyclones. For example, cross-front temperature differences are expected to be higher (lower) for considerably colder (warmer) climates (Pfahl et al., 2015, their Fig. 10), whereas the associated precipitation is expected to decrease (increase; their Fig. 12) due to the strong limiting effect of temperature on the atmospheric moisture content.

One important issue preventing non-recent or non-21stcentury cyclone analysis is the availability of climate model output with sufficient spatial and temporal resolution to enable identification, tracking and characterisation of such cyclones. For example, model data from the PMIP3 project (Braconnot et al., 2012) are only archived 6-hourly for short (30-year) time slices and typically at a low resolution (approximately 200-300 km). Most pre-20th-century studies consider aggregated measures of cyclone (or synoptic) activity (e.g. Kageyama et al., 1999; Laine et al., 2009; Hofer et al., 2012; Ludwig et al., 2016), thus not enabling a detailed comparison to regional temperature and precipitation variability. One period of particular interest is the Last Glacial Maximum (LGM; Clark et al., 2009), when the European climate was characterised by colder and mostly drier conditions (Bartlein et al., 2011; Annan and Hargreaves, 2013; Újvári et al., 2017; Cleator et al., 2019). Large parts of northern Europe were covered by permanent ice sheets and surrounded by polar desert conditions (Ray and Adams, 2001). Western, central and eastern Europe were largely characterised by open shrublands and grasslands (steppe tundra), while in southern Europe steppe with embedded forest (forest steppe) dominated (Ray and Adams, 2001). Under these conditions, dust storms triggered by strong winds must have been common in Europe, as documented by the major loess deposits found primarily around $50^{\circ} \mathrm{N}$ over western and central $\mathrm{Eu}-$ rope and over large parts of eastern Europe (Antoine et al., 2009, 2013; Sima et al., 2013; Újvári et al., 2017).

Under the influence of the continental ice sheets and extended sea ice, the PMIP3 general circulation models (GCMs) show stronger meridional temperature gradients, leading to a southward-displaced, more intense and less variable North Atlantic jet than under current climate conditions (Löfverström et al., 2014, 2016; Merz et al., 2015; Wang et al., 2018). These differences have been related, e.g. to more dominant cyclonic Rossby wave breaking near Greenland (Riviére et al., 2010), stationary wave packets trapped in the midlatitude wave guide (Löfverström, 2020) and enhanced meridional eddy momentum flux convergence over the North Atlantic (Wang et al., 2018). In line with a southward-displaced and stronger jet stream, several studies show a more intense and southward-shifted North Atlantic storm track compared to today's climate (e.g. Hofer et al., 2012; Luetscher et al., 2015; Ludwig et al., 2016). However, other studies display reduced storm track activity over the North Atlantic in spite of the enhanced baroclinicity (e.g. Donohoe and Battisti, 2009; Riviére et al., 2010; Löfverström et al., 2016). Riviére et al. (2018) discusses a reduced baroclinic conversion as a possible reason for this apparent discrepancy, arguing that the eddy heat fluxes are less well aligned with the mean temperature gradient for LGM than for the pre-industrial (PI) conditions. Other arguments for the reduced storminess include model resolution, parameterisations and boundary conditions (e.g. Donohoe and Battisti, 2009; Riviére et al., 2018). Thus, the intensity differences between LGM and PI North Atlantic storm track activity may be model dependent.

The PMIP3 models show indications that while Europe was largely drier than today, this was not the case for some regions, notably for the Iberian Peninsula (e.g. Hofer et al., 2012; Beghin et al., 2016; Ludwig et al., 2016). However, wetter conditions over the Iberian Peninsula are not in line with (most of) the proxy data, which themselves are often associated with considerable uncertainties (e.g. Bartlein et al., 2011; Moreno et al., 2014; Cleator et al., 2019). Nevertheless, the substantial misrepresentation of the regional climate for the LGM in PMIP3 models compared to proxies is regarded as a general issue (Harrison et al., 2015). In some cases, such caveats can be partially traced back to shortcomings of the GCMs and/or their boundary conditions. For example, Ludwig et al. (2017) implemented more realistic boundary conditions in terms of the North Atlantic sea surface temperatures (SSTs), land use types and vegetation cover in a regional climate model (RCM) to simulate the regional climate under LGM conditions. Their results in terms of LGM temperature, precipitation and the permafrost margin are in better agreement with the proxies than without the implemented boundary conditions. Still, further studies are needed, notably at the regional scale (e.g. Ludwig et al., 2018), in order to further our confidence in the modelling capabilities and our understanding of the palaeoclimate conditions for Europe in key periods like the LGM (Harrison et al., 2015, 2016; Ludwig et al., 2019).

The present work aims to advance our understanding of the LGM climate over the North Atlantic and Europe through a more detailed analysis of the cyclonic activity and its associated impacts, notably in terms of precipitation, temperature and wind speed. The LGM cyclones are first identified and tracked on a simulation with the coupled MPI-ESM-P model, for which data with high temporal resolution were archived. Secondly, a subsample of extreme cyclones is downscaled with a RCM to analyse possible changes in LGM cyclone characteristics compared to their modern counterparts at high spatial and temporal resolution. The identified characteristics of LGM extreme cyclones are discussed in terms of the available proxies for LGM climate across western Europe. In addition to the precipitation and temperature, the importance of 
the dominant land cover conditions and the frequent occurrence of dust storms is evaluated. The final section presents the summary and main conclusions.

\section{Data and methods}

The starting point of our analysis is data from the third phase of the Paleoclimate Modeling Intercomparison Project (PMIP3) (Braconnot et al., 2012) (http://pmip3.lsce.ipsl.fr/, last access: 28 March 2020). The simulations were performed according to the PMIP3 $21 \mathrm{ka}$ experimental design, which includes the lower sea level and blended ice sheet data (Peltier et al., 2015; Lambeck and Chappell, 2001; Lambeck et al., 2002; Tarasov and Peltier, 2002, 2003), orbital parameters and lower greenhouse gas concentrations (see Table 1). From the PMIP3 GCMs, we have selected the MPI-ESM-P (Stevens et al., 2013; Jungclaus et al., 2013) constant forcing simulations, for which two 30-year time slices with 6hourly output data are available for PI and LGM conditions. This choice was motivated by the availability of 6-hourly 3D model level data needed for running the RCM. Ludwig et al. (2016) recently analysed a small ensemble of PMIP3 models in terms of large-scale circulation for Europe, jet stream synoptic activity, precipitation and temperature for the LGM. While the Max Planck Institute for Meteorology Earth System Model in Paleo Mode (MPI-ESM-P) has a slightly different jet structure to some of the other PMIP3 models (cf. Ludwig et al., 2016; their Fig. 2), which also impacts, for example, the storm track and precipitation (their Figs. 4, 6), its main characteristics are generally close to the ensemble average.

Individual extratropical cyclones over the North Atlantic and Europe are identified and tracked based on 6-hourly mean sea level pressure data with a widely used automatic tracking algorithm (Murray and Simmonds, 1991; Pinto et al., 2005). The resulting cyclone statistics provide information on the lifetime of each identified cyclone, thus enabling the computation of mean cyclone statistics like track density, mean maximum intensity, cyclogenesis, cyclolysis, propagation speed and deepening rates. Cyclone statistics obtained with this method compare well with other methodologies (e.g. Neu et al., 2013; Hewson and Neu, 2015). Following Pinto et al. (2009), cyclones are selected based on the following conditions: (a) cyclone lifetime of at least $24 \mathrm{~h}$, (b) a minimum core mean sea level pressure (MSLP) value below $1000 \mathrm{hPa}$, (c) a maximum vorticity (approximated by the Laplacian of MSLP) value above $0.6 \mathrm{hPa}$ deg. lat. ${ }^{-2}$ and (d) a maximum deepening rate of $0.3 \mathrm{hPadeg}$. lat. ${ }^{-2} \mathrm{~s}^{-1}$ is achieved at least once during their lifetime. The method is applied here to the MPI-ESM-P data for the extended (ONDJFM) winter season. In order to analyse the characteristics of the most extreme cyclones affecting Europe in more detail, the most intense 30 cyclones (top 30) for the PI and LGM periods are selected based on their peak intensity in terms

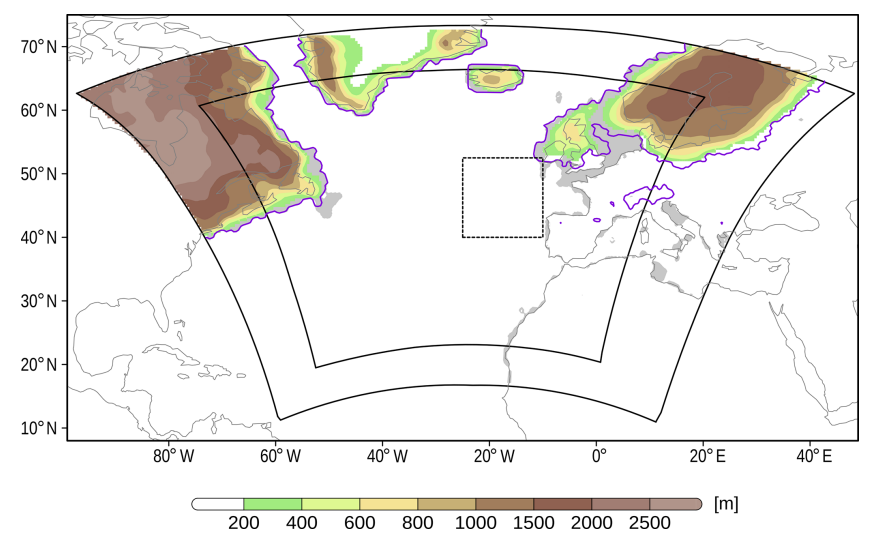

Figure 1. WRF model domains (outer solid box: $50 \mathrm{~km}$ grid spacing; inner solid box: $12.5 \mathrm{~km}$ grid spacing), ice sheet heights (m) (coloured) and extents (purple line), land-sea mask (additional land areas grey) as obtained from PMIP3; the target area for cyclone detection is marked by the dotted box.

of vorticity and their passage within a pre-defined box over the eastern North Atlantic (Fig. 1, dashed box). The selection of the box enables the creation of a cyclone ensemble that impacts western Europe and permits a comparison with terrestrial proxy data, e.g. for precipitation and dust.

The Weather Research and Forecasting (WRF) model (Skamarok et al., 2008) is used in version 3.9.1.1 to simulate the top 30 cyclones (from PI and LGM) with a grid spacing of $12.5 \mathrm{~km}$ (including 35 vertical layers up to $30 \mathrm{hPa}$ ). To achieve a grid spacing of $12.5 \mathrm{~km}$, a two-step nesting approach is necessary. Cyclones were initially simulated on a $50 \mathrm{~km}$ grid forced by MPI-ESM-P data as initial and boundary conditions with an update frequency of $6 \mathrm{~h}$. The final $12.5 \mathrm{~km}$ grid spacing is achieved by a second nesting step within the WRF model. An overview of the parameterisation choices is given in Table 2. For the calculation of wind gusts, a gust parameterisation based on $10 \mathrm{~m}$ wind speed and friction velocity (Schulz and Heise, 2003; Schulz, 2008) has been implemented into the WRF model. This gust parameterisation shows overall good agreement with observed wind gusts, particularly over flat terrain (Born et al., 2012). For the WRF simulations, global PI and LGM boundary conditions were adapted considering specifications of the PMIP3 protocol (Braconnot et al., 2012; see also Ludwig et al., 2017). These changes encompass orbital parameters, trace gases (see Table 1), the consideration of ice sheets (extent and height), an associated lowering of the sea level and adaption of land use cover (CLIMAP Project Members, 1984).

The top 30 cyclone tracks simulated by WRF were identified manually based on relative vorticity field at $850 \mathrm{hPa}$. For comparison of the PI and LGM cyclone characteristics, and following the methodology from Catto et al. (2010; their Fig. 3), each track was rotated so that the cyclones were each moving in west-east directions, enabling the generation of composites for different atmospheric variables (cf. 
Table 1. Boundary conditions adapted in the WRF simulations for PI and LGM based on the PMIP3 protocol.

\begin{tabular}{lrrrrrr}
\hline & $\mathrm{CO}_{2}$ & $\mathrm{~N}_{2} \mathrm{O}$ & $\mathrm{CH}_{4}$ & Eccentricity & Obliquity & Angular precession \\
\hline PI & $280 \mathrm{ppm}$ & $270 \mathrm{ppb}$ & $760 \mathrm{ppb}$ & 0.01672 & $23.446^{\circ}$ & 102.04 \\
LGM & $185 \mathrm{ppm}$ & $200 \mathrm{ppb}$ & $350 \mathrm{ppb}$ & 0.01899 & $22.949^{\circ}$ & 114.42 \\
\hline
\end{tabular}

Table 2. Physical parameterisation schemes used in the regional model simulations (same parameterisations used for 50 and $12.5 \mathrm{~km}$ domains). PBL indicates the planetary boundary layer. Bold numbers indicated the chosen namelist parameters.

\begin{tabular}{|c|c|c|c|c|c|}
\hline & Microphysics & Cumulus scheme & PBL scheme & Radiation scheme & Surface \\
\hline $\begin{array}{l}\text { WRF namelist } \\
\text { option }\end{array}$ & 95 (Eta (Ferrier) $)$ & 6 (Tiedke) & $\begin{array}{l}2 \text { (Mellor- } \\
\text { Yamada-Janjic) }\end{array}$ & SW/LW: 4 (RRTMG) & 2 (Noah LSM) \\
\hline Reference & Ferrier et al. (1995) & Zhang et al. (2011) & Janjic (1994) & Iacono et al. (2008) & Tewari et al. (2004) \\
\hline
\end{tabular}

Dacre et al., 2012). Composites have been created for peak intensity (0) and 6, 12, 18 and $24 \mathrm{~h}$ before peak intensity, and 6 and $12 \mathrm{~h}$ afterwards. For brevity, we will primarily discuss the time frames of (i) $12 \mathrm{~h}$ before peak intensity and (ii) peak intensity. The variables analysed from the $12.5 \mathrm{~km}$ WRF simulations include mean sea level pressure, precipitation, column-integrated water vapour, $850 \mathrm{hPa}$ equivalentpotential temperature, $925 \mathrm{hPa}$ winds, and near-surface wind gusts.

\section{Northern Hemisphere cyclone statistics for PI and LGM conditions}

In this section, we analyse the general characteristics of cyclones over the North Atlantic and Europe under LGM conditions and compare them to PI climate conditions. Figure 2 shows the cyclone track density for the extended winter for PI and LGM climate conditions. In spite of the lower spatial resolution of MPI-ESM-P, the cyclone track density for PI is close to cyclone statistics obtained with reanalysis datasets, with a slight southerly shift of cyclonic activity (see Fig. S1 in the Supplement for comparison with NCEP reanalysis data of Kalnay et al., 1996) and CMIP GCMs for recent climate conditions (cf. Pinto et al., 2007; their Fig. 1). Still, some regional shortcomings are identified, notably the limited cyclone activity over the Mediterranean basin. The North Atlantic storm track shows a clear tilt towards northern Europe and the Arctic Ocean for PI, and its location and orientation are closely related with the eddy-driven jet stream (black contours in Fig. 2a) and the associated upper-air baroclinicity (Hoskins and Valdes, 1990; Pinto et al., 2009). A comparison of the jet stream between MPI-ESM-P PI and NCEP reanalysis data shows a slight tilt towards Europe by the MPI model (Fig. S2), in line with the enhanced (reduced) southward (northward) cyclone activity (Fig. S1).

The North Atlantic storm track looks quite different under LGM conditions relative to PI: the cyclone track density is higher over the North Atlantic and more constrained to the ice edge (Figs. 2b, S1). Close to Europe, a bifurcation is found, and cyclones are either deflected northward along the border of the Scandinavian ice sheet or southeastward towards central Europe and the Mediterranean (Fig. 2c). In accordance, the eddy-driven jet is stronger under LGM conditions in the MPI-ESM-P (Fig. S2), thus establishing more favourable conditions for the occurrence of intense storms affecting western and central Europe. For the North Atlantic $\left(35-70^{\circ} \mathrm{N}, 70^{\circ} \mathrm{W}-0\right)$, the total number of cyclones for the analysed 30-year period is about $26 \%$ larger for LGM than for PI conditions (12071 vs. 9541 individual cyclone counts in 30 years, corresponding to roughly 2.2 cyclones $\mathrm{d}^{-1}$ vs. 1.8 cyclones $\mathrm{d}^{-1}$ ).

Other properties of cyclone activity are depicted in Fig. 3 for LGM in terms of absolute values (left column) and their differences to PI (right column). Cyclogenesis is dominant along the North American east coast for the LGM (Fig. 3a) and much stronger than in PI (Fig. 3b), which is in line with a much stronger upper-level jet stream during glacial conditions. Moreover, the rate of cyclogenesis increased south of Greenland and over western and central Europe. On the other hand, there is more cyclolysis along the borders of the Greenland and Scandinavian ice sheets (Fig. 3c) relative to the PI conditions (Fig. 3d). Mean maximum cyclone intensity is typically attained in a region extending from Newfoundland to Iceland and the British Isles, with a secondary maximum over eastern Europe (Fig. 3e). Compared to the PI cyclones, the LGM cyclones have stronger intensities, particularly in an area extending from the south of Greenland to the British Isles and over most of continental Europe. On the other hand, cyclone intensity close to the North American east coast is considerably lower (Fig. 3f). Deepening rates are stronger for LGM cyclones over the central north Atlantic, as well as their filling rates close to the ice edge/ice sheets (Fig. $3 \mathrm{~g}$, h). These results point towards different typical development of LGM cyclones compared to their PI counterparts, which occurs either more zonally at lower latitudes towards central 

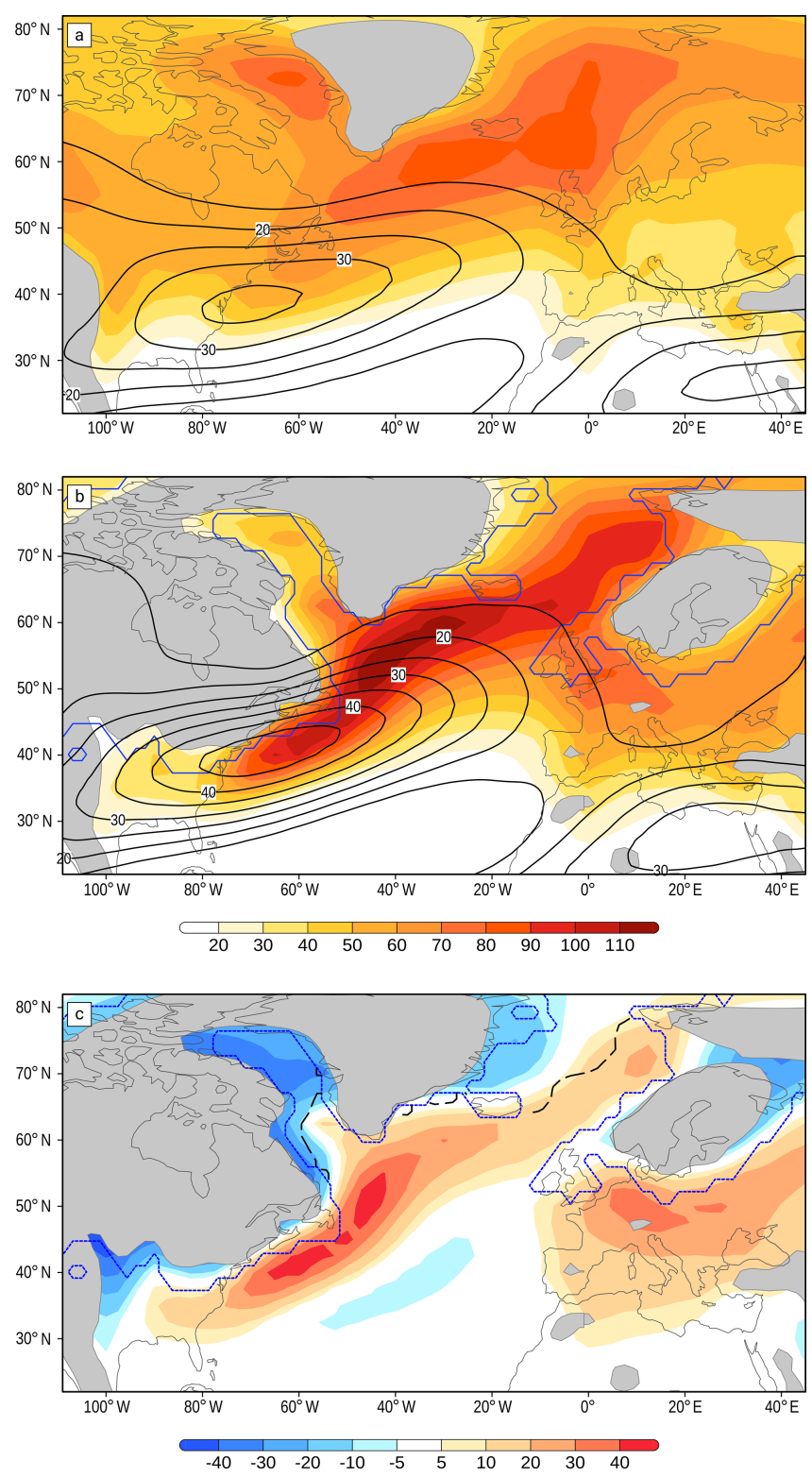

Figure 2. Cyclone track density (cyclone days per extended winter per (deg. lat.) $)^{2}$ (coloured) and $300 \mathrm{hPa}$ wind speed $\left(\mathrm{m} \mathrm{s}^{-1}\right.$ ) (contours) based on MPI-ESM-P data for (a) PI, (b) LGM and (c) difference between LGM and PI. Areas with topography higher than $1000 \mathrm{~m}$ are shaded grey; ice sheet margins $(\mathbf{b}, \mathbf{c})$ are denoted by the thin stippled line; the long dashed black line in panel (c) denotes the margin of $40 \%$ annual sea ice cover.

Europe or further downstream closer to the ice edge towards the Arctic.

Figure 4 displays the relative frequency distribution of the cyclone intensity over the North Atlantic area $\left(35-70^{\circ} \mathrm{N}, 70^{\circ} \mathrm{W}-0\right)$, revealing that LGM cyclones are on average more intense (mean (median): 1.58 (1.41) hPa deg. lat. ${ }^{-2} \mathrm{~s}^{-1}$ ) than their PI counterparts (mean (median): 1.43 (1.28) $\mathrm{hPadeg}$. lat. ${ }^{-2} \mathrm{~s}^{-1}$ ). In particular, the number of cyclones exceeding $3 \mathrm{hPa}$ deg. lat. ${ }^{-2} \mathrm{~s}^{-1}$ is twice as large for LGM as for PI. In fact, a small number (18) of LGM cyclones attain intensities exceeding the range identified for PI cyclones. The statistics for the region close to Europe (box) are similar (not shown). All these results document a shift towards stronger intensities for LGM cyclones, both in terms of average numbers and extreme values.

\section{Characteristics of extreme cyclones over the eastern North Atlantic}

To analyse the characteristics of cyclones for the LGM, a subset of 30 extreme cyclones passing over the eastern North Atlantic is selected for both the PI and LGM periods based on the highest values for vorticity (Laplacian of MSLP) within the selected box. The trajectories of the selected MPI-ESM cyclones are depicted in Fig. 5 and key information is given in Table 3. Two important facts are clearly identifiable: LGM extreme cyclone trajectories are more zonally orientated and constrained to a narrower corridor (particularly until $15^{\circ} \mathrm{W}$ ) than their PI counterparts, and they achieve higher vorticity (mean Laplacian of MSLP for LGM: 2.80; PI: 2.52) values during lifetime (Table 3).

For each of these cyclones, WRF simulations down to $12.5 \mathrm{~km}$ grid spacing are performed along the most intense segment of their lifetimes, thus gaining 3-D data to analyse the cyclones, e.g. in terms of the evolution of their structure, air masses, winds and precipitation. Care was taken that storms agree between the original MPI-ESM-P data and WRF cyclone tracks. Generally, the obtained tracks based on the WRF simulations reveal lower core pressures and higher vorticity than their low-resolution counterparts. Figure 6 shows a comparison between high- and low-resolution data for a selected cyclone. The considered cyclone tracks (MPI-ESM LGM cyclone no. 24) show a good superimposition for MPI-ESM, WRF $50 \mathrm{~km}$ and WRF $12.5 \mathrm{~km}$ and good agreement of the position of maximum intensity with a slightly further southeastward location for WRF $50 \mathrm{~km}$ (Fig. 6a). While the time series, centred at peak intensity, for the development of core pressure show a similar strong pressure drop for all resolutions, the relative vorticity exhibits much stronger values for the high-resolution simulation (WRF $12.5 \mathrm{~km}$ ) in comparison to the coarser realisations. Note that the WRF simulations do not cover the whole trajectory of the cyclones, and thus the time series are shorter. Figure $6 \mathrm{c}$ and $\mathrm{d}$ depict the corresponding precipitation patterns at peak intensity, in this case revealing more small-scale structures and higher precipitation values for the $12.5 \mathrm{~km}$ WRF simulation.

Based on the top 30 cyclones for PI and LGM and using the composite methodology described in Sect. 2, average cyclone characteristics are investigated for the intensification phase, focussing on the time frames (i) $12 \mathrm{~h}$ before peak intensity and (ii) peak intensity. Figure 7 displays the MSLP 

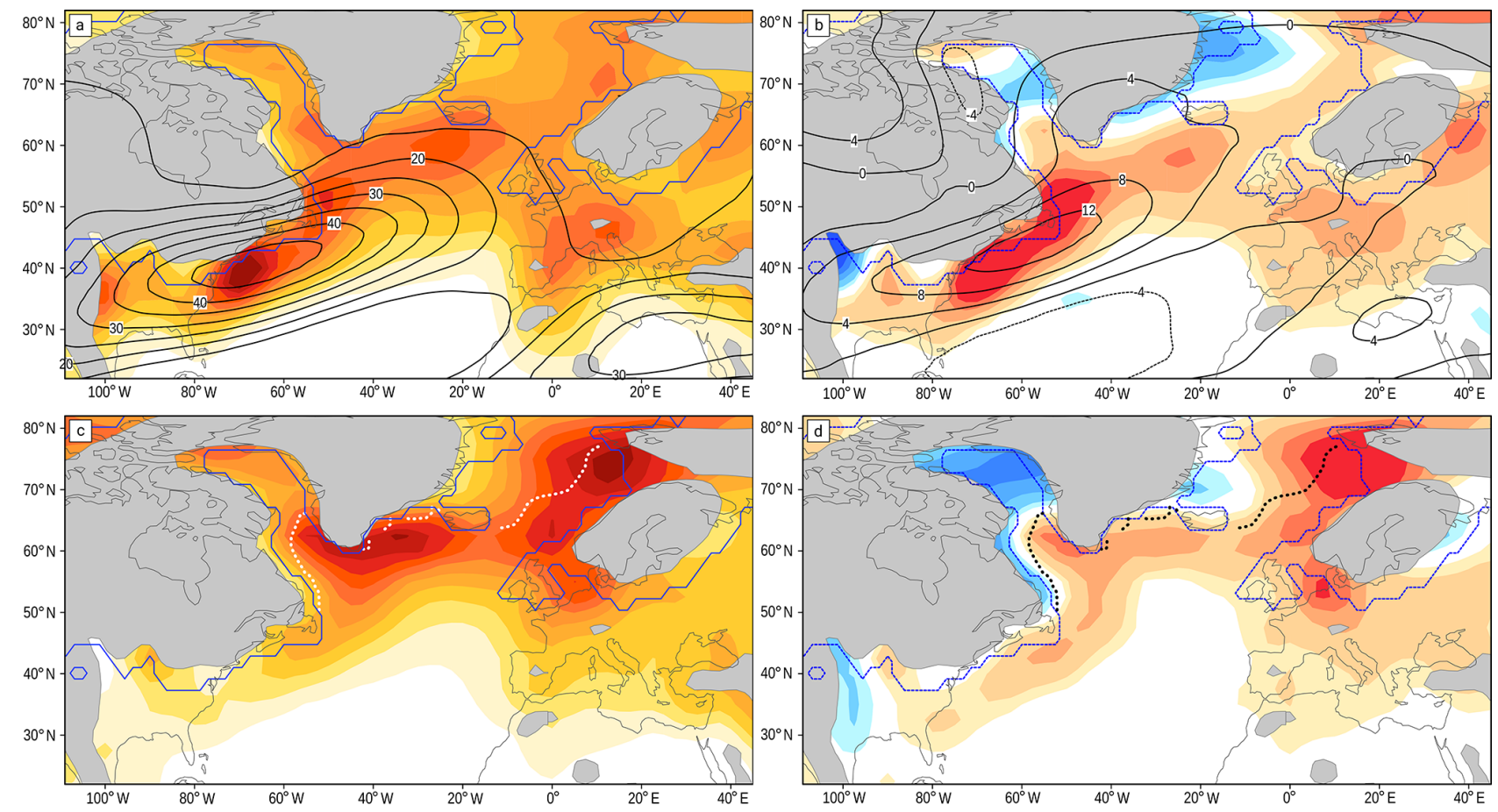

$\begin{array}{llllllllll}0.2 & 0.4 & 0.6 & 0.8 & 1 & 1.2 & 1.4 & 1.6 & 1.8 & 2\end{array}$
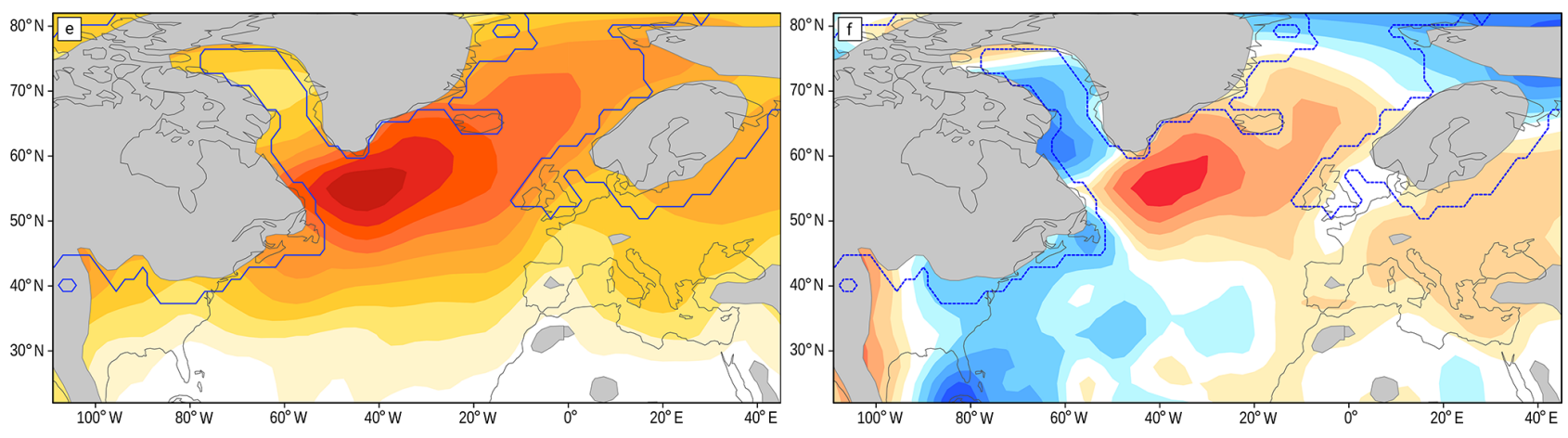

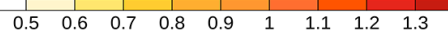
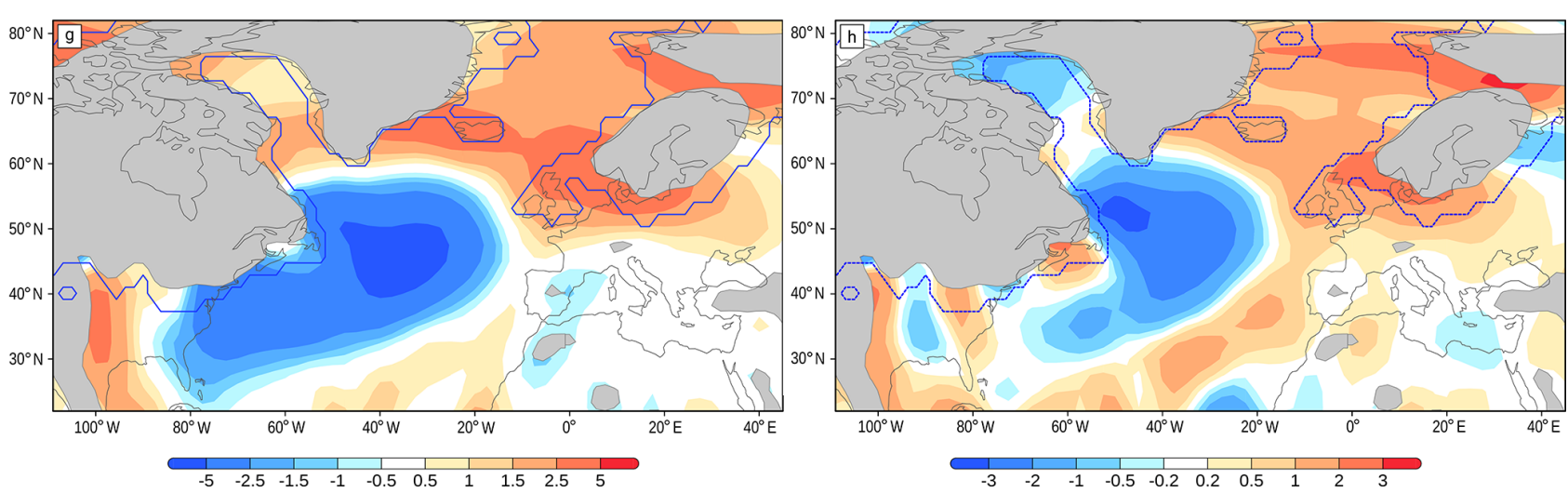

Figure 3. Statistical measures obtained from the cyclone-tracking algorithm for LGM cyclones (left column) and difference with PI cyclones

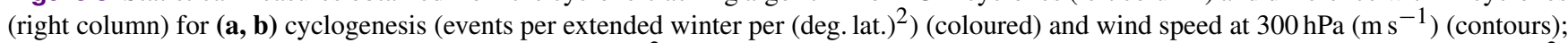
$(\mathbf{c}, \mathbf{d})$ cyclolysis (events per extended winter per (deg. lat.) $\left.{ }^{2}\right) ;(\mathbf{e}, \mathbf{f})$ mean $\Delta$ MSLP (Laplacian of pressure per extended winter per $(\text { deg. lat. })^{2}$ ) and $(\mathbf{g}, \mathbf{h})$ deepening rates $\left(\mathrm{hPa} \mathrm{h}^{-1}\right)$. Areas with topography higher than $1000 \mathrm{~m}$ are shaded grey; ice sheet extent is marked by the blue line. Sea ice margin ( $>40 \%$ annual cover) in panels (c) and (d) is indicated by the bold dashed lines. 

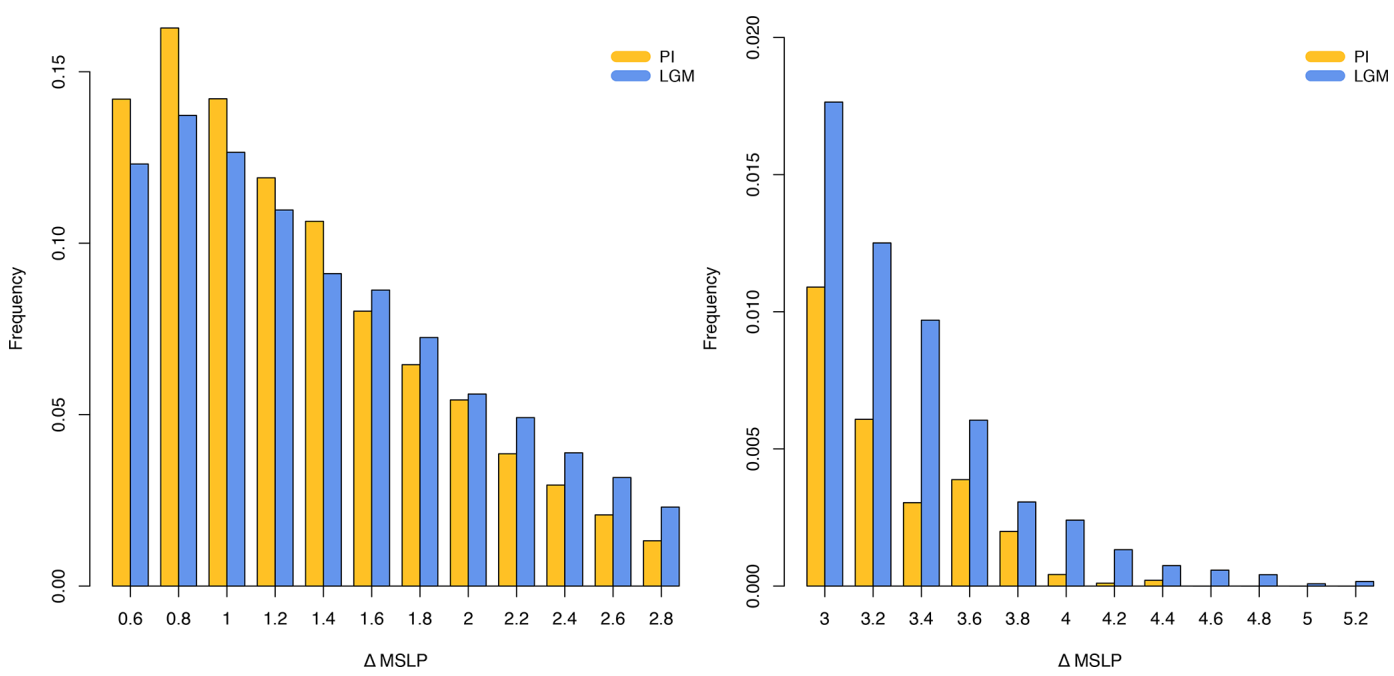

Figure 4. Histogram of cyclone intensity (Laplacian $(\Delta)$ MSLP) over the North Atlantic $\left(35-70^{\circ} \mathrm{N}, 70^{\circ} \mathrm{W}-0\right)$. For intense cyclones $(\Delta P \geq$ 3), the $y$ axis is adjusted (right panel).

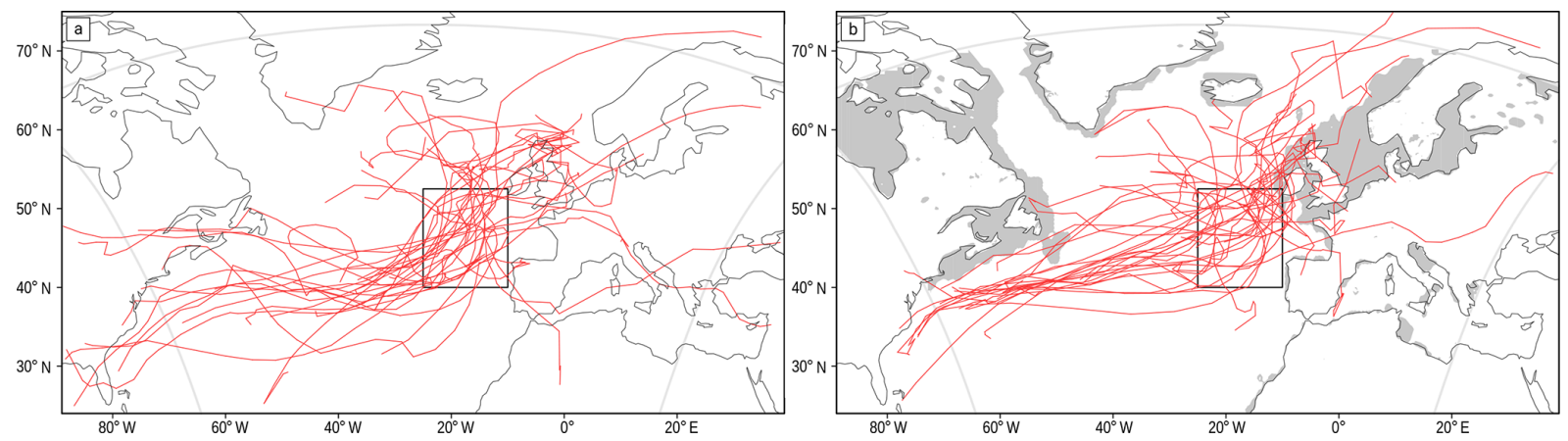

Figure 5. Cyclone tracks of top 30 (a) PI and (b) LGM cyclones (MPI-ESM). The black box indicates the region where cyclones need to have maximum intensity to be considered in the composite analysis.

fields for PI and LGM for peak intensity; the corresponding panels for $12 \mathrm{~h}$ before peak intensity can be found in Fig. S3. The anomalies compared to the mean MSLP are displayed in colours, in order to analyse MSLP gradients (Figs. 7a, b; S3a, b). The core MSLP of the LGM has higher values compared to PI (LGM: $982.7 \mathrm{hPa}$, PI: $975.2 \mathrm{hPa}$ ). This can be explained by the lower sea levels $(\sim 120 \mathrm{~m})$ for LGM, causing a difference of global mean sea level pressure of about $\sim 13 \mathrm{hPa}$ (PI: $1010 \mathrm{hPa}$, LGM: $1023 \mathrm{hPa}$ ). Taking this into account, the LGM cyclones reach deeper MSLP values compared to the global average MSLP, being consistent with the stronger deepening rates for LGM cyclones identified by the tracking algorithm (Fig. 3g, h). Additionally, the closer isobars south of the cyclone core indicate stronger pressure gradients for the LGM cyclones, which is supported by the LGM - PI differences (Fig. 7c). This is particularly the case on the expected location of the frontal areas. Figures 7d, e and S3d, e display the anomalies of equivalent-potential temperature $\left(\theta_{\mathrm{E}}\right)$ at $850 \mathrm{hPa}$ for LGM relative to PI. Results show that the cross-frontal gradients are particularly intense across the warm front and that the whole development is displaced forward in the cyclone for LGM conditions, indicating a faster occlusion (Fig. 7f). On the other hand, the total water content is much higher under PI conditions, primarily due to the effect of the higher environmental temperatures (Figs. 7g, h; $\mathrm{S} 3 \mathrm{~g}, \mathrm{~h}$ ) with differences in the warm sector reaching up to 10 and $6-8 \mathrm{~mm}$ close to the cyclone core at peak intensity (Fig. 7i).

The strong difference in available water content again leads to a large difference in terms of accumulated precipitation, which is clearly larger for the PI composites (Figs. 8a, b; S4a, b). While some of the smaller deviations can be potentially attributed to slightly different developments, the total precipitation is considerably lower for the LGM extreme cyclones (up to $1.7 \mathrm{~mm} \mathrm{~h}^{-1}$ ) particularly in the area of peak precipitation close to the cyclone centre (Fig. 8c). On the other hand, wind speed at $925 \mathrm{hPa}$ is much higher for LGM cyclones (Figs. 8d, e; S4d, e), where wind speeds over large areas south of the cyclone exceed their PI counterparts by $10-12 \mathrm{~ms}^{-1}$, particularly for $12 \mathrm{~h}$ before peak intensity 
Table 3. Overview of time and location of maximum intensity (defined by the maximum of the Laplacian of MSLP) of the top 30 MPI-ESM-P cyclones for PI and LGM conditions inside the box (Fig. 1).

\begin{tabular}{|c|c|c|c|c|c|c|c|c|c|c|}
\hline & \multicolumn{5}{|c|}{ PI } & \multicolumn{5}{|c|}{ LGM } \\
\hline & Date & Time & Lapl P & ${ }^{\circ}$ Lat & ${ }^{\circ}$ Long & Date & Time & Lapl P & ${ }^{\circ}$ Lat & ${ }^{\circ}$ Long \\
\hline 1 & 29930107 & 18 & 3.162 & 51.54 & 342.98 & 19360211 & 00 & 3.535 & 52.33 & 338.93 \\
\hline 2 & 29960104 & 12 & 3.158 & 51.96 & 343.35 & 19311012 & 18 & 3.430 & 47.35 & 335.87 \\
\hline 3 & 29901123 & 18 & 2.858 & 44.31 & 340.09 & 19361122 & 00 & 3.220 & 46.53 & 341.67 \\
\hline 4 & 29941108 & 18 & 2.811 & 41.67 & 339.00 & 19421024 & 06 & 3.202 & 52.34 & 345.53 \\
\hline 5 & 29830317 & 06 & 2.786 & 45.87 & 335.95 & 19220117 & 06 & 3.067 & 46.62 & 337.56 \\
\hline 6 & 29980131 & 00 & 2.734 & 49.97 & 336.31 & 19400228 & 12 & 2.965 & 50.20 & 348.23 \\
\hline 7 & 29941115 & 06 & 2.628 & 49.90 & 343.87 & 19411118 & 06 & 2.962 & 49.70 & 343.95 \\
\hline 8 & 29800114 & 18 & 2.615 & 47.33 & 347.16 & 19321113 & 00 & 2.917 & 52.11 & 346.19 \\
\hline 9 & 29980225 & 18 & 2.572 & 49.45 & 335.94 & 19271125 & 06 & 2.911 & 43.70 & 337.33 \\
\hline 10 & 29991024 & 12 & 2.551 & 50.82 & 345.56 & 19211225 & 06 & 2.894 & 45.19 & 345.36 \\
\hline 11 & 29831230 & 06 & 2.541 & 41.97 & 336.09 & 19251112 & 18 & 2.850 & 46.88 & 348.18 \\
\hline 12 & 29851122 & 12 & 2.528 & 48.60 & 349.10 & 19440128 & 00 & 2.823 & 43.52 & 335.73 \\
\hline 13 & 29990207 & 18 & 2.512 & 43.76 & 344.89 & 19400325 & 18 & 2.812 & 49.81 & 335.18 \\
\hline 14 & 29940209 & 12 & 2.511 & 46.31 & 345.74 & 19420113 & 00 & 2.746 & 52.13 & 337.36 \\
\hline 15 & 29891222 & 00 & 2.493 & 51.81 & 342.91 & 19371028 & 00 & 2.728 & 45.43 & 348.59 \\
\hline 16 & 29790224 & 00 & 2.491 & 50.35 & 344.83 & 19230328 & 18 & 2.725 & 50.70 & 349.34 \\
\hline 17 & 30031202 & 06 & 2.489 & 42.45 & 344.77 & 19401105 & 18 & 2.688 & 51.82 & 346.50 \\
\hline 18 & 30010105 & 18 & 2.473 & 48.50 & 339.35 & 19220108 & 06 & 2.679 & 42.31 & 342.38 \\
\hline 19 & 29850119 & 18 & 2.471 & 43.52 & 338.38 & 19230204 & 12 & 2.678 & 48.73 & 342.70 \\
\hline 20 & 29870105 & 12 & 2.466 & 47.53 & 345.43 & 19350103 & 18 & 2.663 & 51.29 & 339.74 \\
\hline 21 & 29961123 & 00 & 2.457 & 46.23 & 337.72 & 19351217 & 00 & 2.635 & 52.12 & 342.00 \\
\hline 22 & 30001223 & 06 & 2.299 & 47.43 & 345.84 & 19240223 & 00 & 2.613 & 50.39 & 344.81 \\
\hline 23 & 29900221 & 18 & 2.298 & 51.33 & 348.96 & 19331109 & 06 & 2611 & 51.09 & 341.01 \\
\hline 24 & 29811218 & 06 & 2.272 & 47.65 & 345.85 & 19381003 & 12 & 2.590 & 51.91 & 336.29 \\
\hline 25 & 29910118 & 00 & 2.263 & 49.51 & 338.82 & 19430211 & 06 & 2.584 & 48.11 & 348.10 \\
\hline 26 & 29791122 & 12 & 2.252 & 45.25 & 349.74 & 19320213 & 06 & 2.507 & 49.92 & 345.95 \\
\hline 27 & 30040114 & 06 & 2.246 & 44.70 & 340.05 & 19270114 & 06 & 2.497 & 47.66 & 341.06 \\
\hline 28 & 29970210 & 18 & 2.200 & 48.06 & 343.77 & 19371204 & 00 & 2.481 & 43.06 & 336.95 \\
\hline 29 & 30000325 & 00 & 2.167 & 50.88 & 341.08 & 19230203 & 00 & 2.478 & 50.41 & 347.84 \\
\hline 30 & 30031031 & 18 & 2.147 & 46.78 & 347.93 & 19230228 & 12 & 2.448 & 42.46 & 345.65 \\
\hline & Mean & & 2.52 & 47.51 & 342.72 & & & 2.80 & 48.53 & 342.53 \\
\hline & Median & & 2.49 & 47.59 & 343.56 & & & 2.73 & 49.76 & 343.54 \\
\hline
\end{tabular}

(Figs. 8f; S4f). Strong differences are also revealed for nearsurface wind gusts (Figs. 8g-i; $\mathrm{S} 4 \mathrm{~g}-\mathrm{i}$ ). In this case, the wind gusts are particularly enhanced along the expected location of the cold front at peak intensity, with deviations exceeding $5 \mathrm{~ms}^{-1}$. The above-described patterns remain true for the cyclone characteristics $12 \mathrm{~h}$ after peak intensity (Figs. S5, S6). For example, stronger wind gusts remain dominant in the area south of the cyclone core (Fig. S4i).

In summary, LGM cyclones display steeper MSLP gradients (in agreement with higher intensity in terms of circulation), larger temperature gradients between the air masses, weaker precipitation and stronger wind gusts than their PI counterparts do (see also the summary for wind and precipitation in Table S1 in the Supplement).

\section{Discussion with available proxy-based climate reconstructions}

The above analysis shows that extreme cyclones under LGM conditions were typically more intense than PI extreme cyclones. Likewise, they were associated with larger frontal temperature gradients, stronger winds and reduced precipitation. In this section, we analyse in how far these cyclone characteristics can help to explain the climate conditions in western and central Europe at the LGM and the frequent occurrence of dust storms in that area.

According to the available proxy records, western and central Europe were colder and largely drier under LGM conditions (Bartlein et al., 2011; Annan and Hargreaves, 2013; Cleator et al., 2019) and were to a large extent covered by open shrublands and grasslands (Ray and Adams, 2001). The colder and generally drier conditions are reproduced by the 

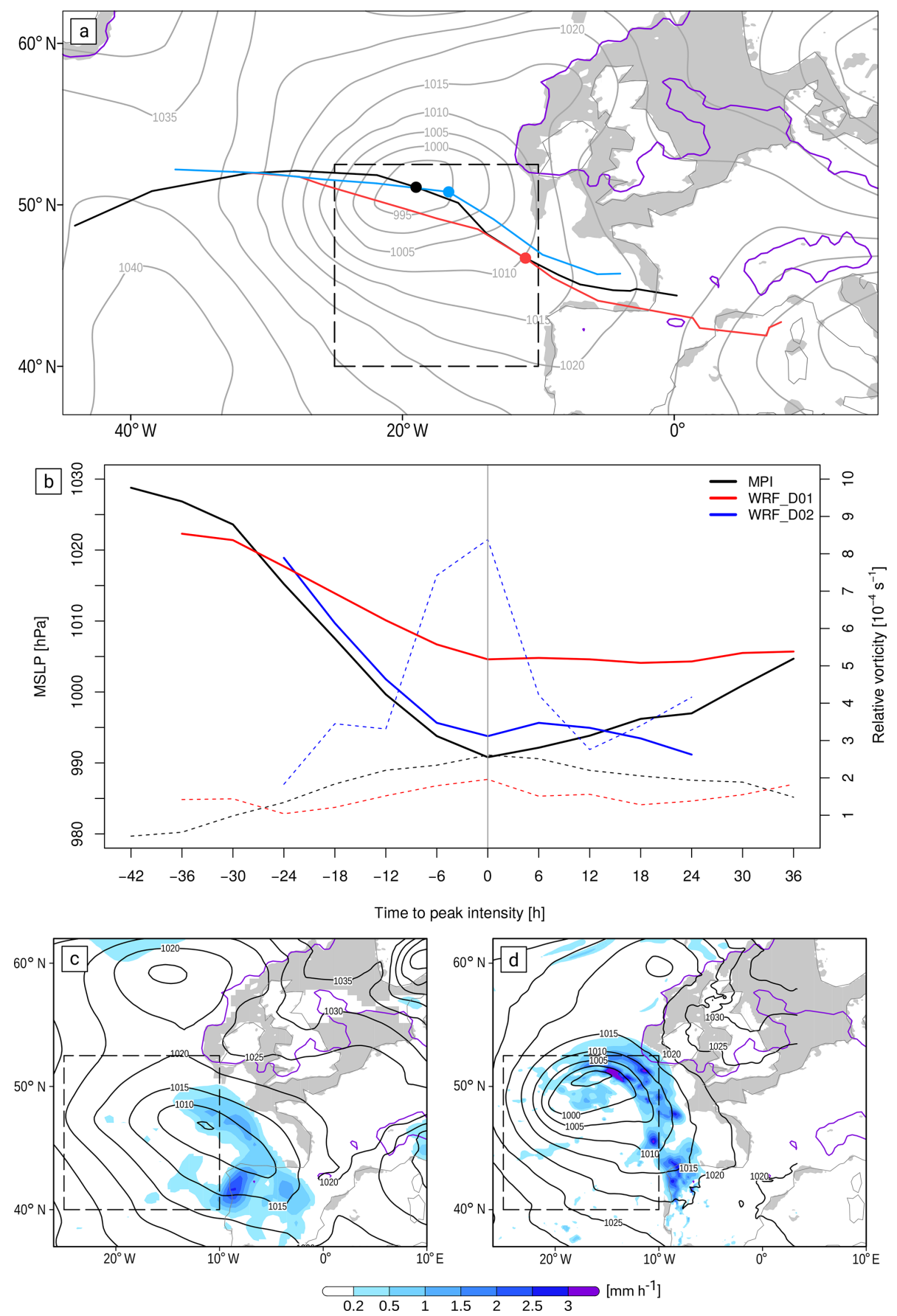

Figure 6. Comparison of (a) cyclone tracks for MPI-ESM (black), WRF $50 \mathrm{~km}$ (red) and WRF $12.5 \mathrm{~km}$ (blue) (coloured dots mark the location of peak intensity; dotted black box shows target area) and MSLP (hPa) for MPI-ESM at peak intensity, (b) time series of cyclone core pressure and relative vorticity for MPI-ESM, WRF $50 \mathrm{~km}$ and WRF $12.5 \mathrm{~km}$ for LGM cyclone no. 24. Simulated precipitation rate $\left(\mathrm{mm} \mathrm{h}^{-1}\right)$ (shaded) and MSLP (hPa) (lines) at peak intensity for (c) WRF $50 \mathrm{~km}$ and (d) WRF $12.5 \mathrm{~km}$.

PMIP3 GCMs, but considerable differences in detail have been identified compared to proxy-based climate reconstructions (Beghin et al., 2016; Ludwig et al., 2016; Cleator et al., 2019). These can be both attributed to shortcomings of the GCMs and/or uncertainties in the reconstructions, which are often not well constrained (Bartlein et al., 2011; Ludwig et al., 2019; Cleator et al., 2019). For example, most PMIP3 GCMs show enhanced precipitation over the Iberian Peninsula compared to PI climate (Beghin et al., 2016; Ludwig et al., 2016), which disagrees with the proxy data (e.g. Bartlein 

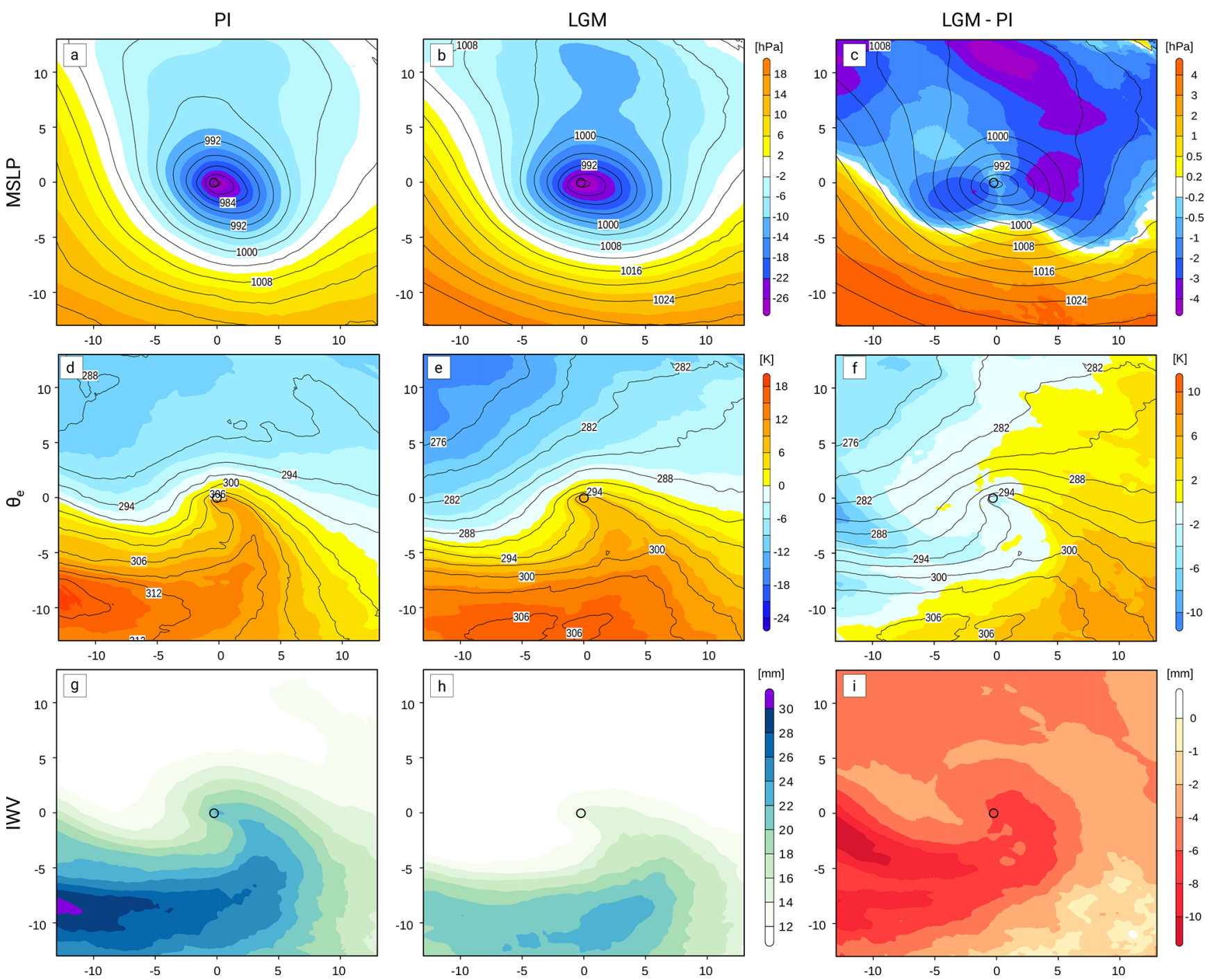

Figure 7. Composites of (a-c) mean sea level pressure, $(\mathbf{d}-\mathbf{f}) \theta_{\mathrm{E}}$ and $(\mathbf{g}-\mathbf{i})$ vertical integrated water vapour (IWV) for PI, LGM and difference LGM - PI at peak intensity as defined by the maximum of the Laplacian of MSLP. (a, b) absolute MSLP values (lines; hPa), anomalies (hPa) from mean over displayed area (coloured); (c) absolute MSLP values (lines; hPa) from LGM, differences of the anomalies between LGM and PI in colours; (d, e) absolute $\theta_{\mathrm{E}}$ values (lines; K) and anomalies (K) from mean over displayed area (coloured); (f) absolute $\theta_{\mathrm{E}}$ values (lines; K) from LGM, differences of the anomalies between LGM and PI in colours; (g, h) absolute IWV values ( $\mathrm{mm}$ ); (i) difference (mm) LGM - PI.

et al., 2011). Later, Ludwig et al. $(2017,2018)$ show that the wet bias over the Iberian Peninsula and western Europe can strongly be reduced by considering more realistic boundary conditions (particularly in terms of sea surface temperatures, land use and vegetation cover) in high-resolution RCM simulations.

The present results enable a more detailed evaluation of the above hypotheses and interpretations. Under current climate conditions, precipitation in the midlatitudes is largely associated with the passage of extratropical cyclones, where extreme cyclones have a comparatively larger contribution to total/extreme precipitation (Pfahl and Wernli, 2012; Hawcroft et al., 2012). Hawcroft et al. (2016) have pro- vided evidence that GCMs typically have shortcomings in representing the precipitation associated with midlatitude cyclones. It is reasonable to assume that those shortcomings may be exacerbated at lower resolutions, e.g. those typical of the PMIP3 models. An idealised study by Pfahl et al. (2015) has shown that precipitation increases (decreases) disproportionately in considerably warmer (colder) climate conditions. With the help of the high-resolution WRF simulations, we could provide evidence that extreme cyclones under LGM conditions indeed induce considerably less precipitation than their PI counterparts $\left(\sim 22 \%\right.$ within a $10^{\circ}$ radius around the cyclone centre). Even though lower cyclone-related precipitation may be partially compensated by enhanced moisture 

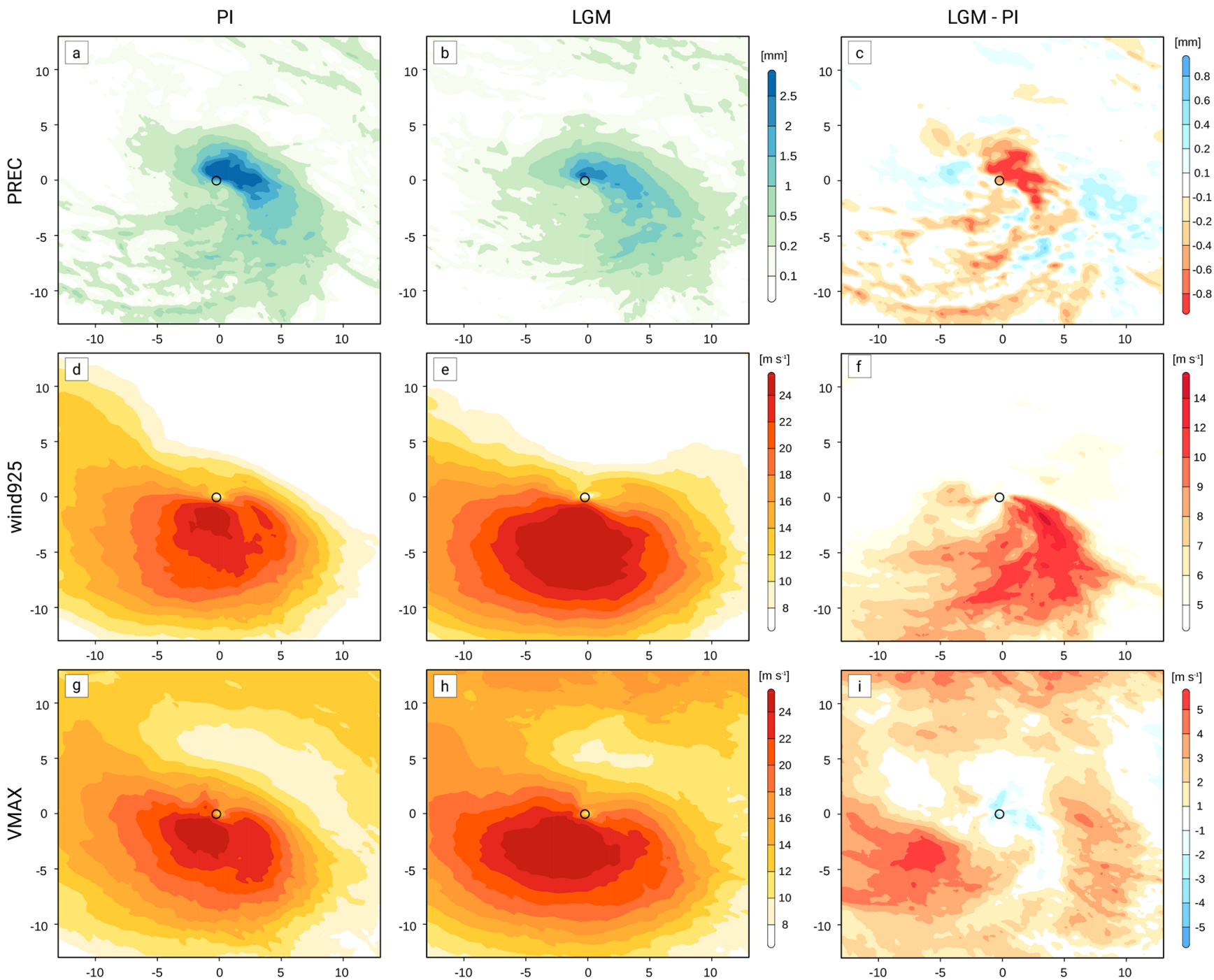

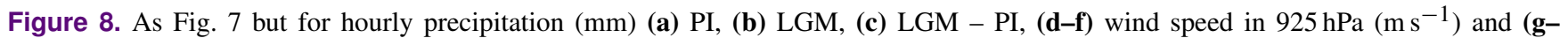
i) maximum near-surface wind gust $\left(\mathrm{m} \mathrm{s}^{-1}\right)$ at peak intensity.

advection embedded in the (stronger) westerly large-scale flow, particularly for areas where orographic precipitation dominates (e.g. upward slopes of mountain ranges/glaciers), it is consistent with the hypothesis of a drier western and central Europe. The view of a drier Europe is also consistent with the dominant land cover types estimated from proxy data (Ray and Adams, 2001) or a statistical reconstruction based on temperature and precipitation (Shao et al., 2018), namely polar desert close to the glaciers, forest steppe over southern Europe and steppe in between. The fact that we have selected an area close to the Iberian Peninsula for cyclone selection leads to the strong assumption that largely drier conditions must also have been found for southwestern Europe, in agreement with the proxies (e.g. Bartlein et al., 2011; Moreno et al., 2014).
Mineral dust plays an important role in our climate system (Shao et al., 2011). Dust emissions are typically initiated by the wind stress on land surfaces with little to no vegetation cover and easily erodible soils (e.g. Prospero et al., 2002). Such areas were very common in Europe under LGM conditions (e.g. Ray and Adams, 2001; Ugan and Byers, 2007), when the global dust cycle is estimated to have been stronger than at present (Maher et al., 2010). A large number of loess deposits over western and central Europe (particularly around $50^{\circ} \mathrm{N}$; Antoine et al., 2009) indicate that dust storms were a common feature of the European climate. In particular, Antoine et al. (2009) identified cyclic variations in loess deposition between 34 and $17 \mathrm{ka}$ at several sites in France, Germany and Belgium, with particularly high sedimentation rates, and attributed these to numerous and intense dust storms in periods with stronger large-scale flow and 
reduced precipitation. Furthermore, the high accumulation rates of loess in the middle and lower Danube basin indicate cold, dry and windy conditions during the LGM in southeastern Europe (Fitzsimmons et al., 2012), consistent with increased storm activity over central Europe (Fig. 2c). These and other findings document a more intense (global) dust cycle for LGM conditions (e.g. Albani et al., 2016; Újvári et al., 2017; Albani and Mahowald, 2019). The occurrence of dust storms over western and central Europe has been conceptually associated with the passage of intense extratropical cyclones penetrating deep into the continent (Antoine et al., 2009; their Fig. 12). Following on previous studies (e.g. Laine et al., 2009; Hofer et al., 2012; Ludwig et al., 2016), the present results provide evidence for the first time that individual LGM cyclones would be indeed capable of triggering such dust events: their frequent tracks over western/central Europe and strong wind could easily trigger dust emission and transport over short (for coarse grain) and large (for fine grain material) distances (cf. Shao et al., 2011). As moisture acts to make surface dust particles more cohesive (e.g. Ishizuka et al., 2008), the reduced cyclone precipitation and higher wind speeds in LGM cyclones would have actually been more conducive to generating dust storms. In addition to the role of the westerlies and embedded cyclones into generating dust storms in Europe, there is evidence that situations with persistent easterlies associated with anticyclonic flow triggered by a strong anticyclone over the Scandinavian ice sheet may have also played a significant role for loess deposition not only over eastern Europe but also over central Europe (Újvári et al., 2017; Schaffernicht et al., 2019).

\section{Summary and conclusions}

The statistics and characteristics of extratropical cyclones over the North Atlantic and western Europe were analysed for time-slice experiments for PI and LGM conditions. First, the statistics of the climatologies of PI and LGM cyclones are analysed and compared based on global MPI-ESM-P simulations. Second, the characteristics of extreme LGM cyclones over the eastern North Atlantic were analysed in detail based on high-resolution simulations (12.5 km grid spacing) with the RCM WRF and compared to their PI counterparts. The results were discussed with available proxy reconstructions of climate parameters and vegetation types. The main conclusions are as follows:

- The North Atlantic storm track was more intense under LGM conditions, featuring more frequent and intense synoptic systems than under PI conditions. One of the downstream branches brought more often extreme cyclones towards western and central Europe and the Mediterranean area.

- LGM cyclones were more intense due to stronger baroclinicity with less influence from diabatic processes (lower rainfall and lower water vapour content). In particular, LGM cyclones benefit from a stronger and extended jet stream. The development was typically faster, with deepening rates and peak intensities exceeding those from PI cyclones.

- LGM extreme cyclones were characterised by lower precipitation, enhanced frontal temperature gradients and stronger mean wind speeds and wind gusts than PI analogues.

- These characteristics are in line with the view of a colder and drier Europe, characterised by steppe tundra land types and affected by frequent dust storms, leading to reallocation and build-up of thick loess deposits.

Given that this study is based on a single GCM, a single tracking method and a single RCM, it should be regarded as a preliminary analysis as the uncertainties of the jet stream position and storm track activity (e.g. Merz et al., 2015; Riviere et al., 2018) may be considerable among different GCMs. Still, the identified differences between PI and LGM (extreme) cyclones are unequivocal, are consistent with idealised studies, demonstrate the potential of the approach and may become instrumental to facilitate a better interpretation of LGM proxy data. In particular, this study provides new understanding of the relationship between the large-scale mean cyclone activity and short-term variability on the regional scale and thus may help to reduce numerical interpretative uncertainties (Harrison et al., 2016).

Even though the added value of RCMs in palaeoclimate applications is still controversially discussed (Armstrong et al., 2019), there is a general call for improvements towards a new generation of reliable regional projections (e.g. Harrison et al., 2015; Kageyama et al., 2018). The present and other studies (see Ludwig et al., 2019 for a review) provide clear arguments for the extended use of RCMs in the scope of palaeoclimate studies, as they can play an important role towards a meaningful joint interpretation of proxies and climate model data. The upcoming new palaeoclimate simulations within CMIP6/PMIP4 (Kageyama et al., 2017, 2018), as well as new proxy-based reconstructions of climates (Cleator et al., 2019), will provide novel possibilities to expand our understanding of past climates and to reduce uncertainties on both the numerical and reconstruction branches.

Data availability. WRF data presented in the paper can be accessed by contacting the authors. The data will be archived at the DKRZ (German Climate Computing Centre). PMIP3 boundary conditions can be obtained at https://pmip3.1sce.ipsl.fr/ (last access: 12 November 2019). Vegetation cover and land use data from CLIMAP (1984) can be obtained at https://iridl.ldeo.columbia.edu/ SOURCES/.CLIMAP/.LGM/ (last access: 12 November 2019). 
Supplement. The supplement related to this article is available online at: https://doi.org/10.5194/cp-16-611-2020-supplement.

Author contributions. Both authors contributed equally to this work. JGP and PL designed the study and the experiments. PL developed the palaeo-specific model adjustments, performed the simulations and prepared the figures. JGP wrote the first draft of the manuscript. JGP and PL contributed with revisions.

Competing interests. The authors declare that they have no conflict of interest.

Acknowledgements. We thank the German Climate Computing Centre (DKRZ, Hamburg) for providing the MPI-ESM-P data and computing resources within DKRZ project 965 "Our Way to Europe - Palaeoclimate and Palaeoenvironmental reconstructions". The authors also thank Alexander Reinbold for his contribution to a preliminary analysis, and Sven Ulbrich for help with the cyclone statistics. The authors are grateful for the support of the PALEOLINK project by the PAGES $2 \mathrm{k}$ network coordinators. We acknowledge support by Deutsche Forschungsgemeinschaft (DFG) and the Open Access Publishing Fund of Karlsruhe Institute of Technology. We thank two anonymous reviewers and Marcus Löfverström for the detailed and helpful comments.

Financial support. This research has been supported by the AXA Research Fund (https://axa-research.org/en/project/joaquim-pinto, last access: (30/03/2020)) and by the Helmholtz Climate Initiative REKLIM (regional climate change; https://www.reklim.de/en) (last access 30/03/2020).

The article processing charges for this open-access publication were covered by a Research Centre of the Helmholtz Association.

Review statement. This paper was edited by Alessio Rovere and reviewed by two anonymous referees.

\section{References}

Albani, S. and Mahowald, N.M.: Paleodust Insights into Dust Impacts on Climate, J. Climate, 32, 7897-7913, https://doi.org/10.1175/JCLI-D-18-0742.1, 2019.

Albani, S., Mahowald, N. M., Murphy, L. N., Raiswell, R., Moore, J. K., Anderson, R. F., McGee, D., Bradtmiller, L. I., Delmonte, B., Hesse, P. P., and Mayewski, P. A.: Paleodust variability since the Last Glacial Maximum and implications for iron inputs to the ocean, Geophys. Res. Lett., 43, 3944-3954, https://doi.org/10.1002/2016GL067911, 2016.

Annan, J. D. and Hargreaves, J. C.: A new global reconstruction of temperature changes at the Last Glacial Maximum, Clim. Past, 9, 367-376, https://doi.org/10.5194/cp-9-367-2013, 2013.
Antoine, P., Rousseau, D.-D., Moine, O., Kunesch, S., Hatté, C., Lang, A., Tissoux, H., and Zöller, L.: Rapid and cyclic aeolian deposition during the Last Glacial in European loess: a highresolution record from Nussloch, Germany, Quaternary Sci. Rev., 28, 2955-2973, https://doi.org/10.1016/j.quascirev.2009.08.001, 2009.

Antoine, P., Rousseau, D. D., Degeai, J.-P., Moine, O., Lagroix, F., Kreutzer, S., Fuchs, M., Hatté, C., Gauthier, C., Svoboda, J., and Lisa, L.: High-resolution record of the environmental response to climatic variations during the Last Interglacial-Glacial cycle in Central Europe: the loess-paleosol sequence of Dolni Vestonice (Cezch Republic), Quaternary Sci. Rev., 67, 17-38, https://doi.org/10.1016/j.quascirev.2013.01.014, 2013.

Armstrong, E., Hopcroft, P. O., and Valdes, P.: Reassessing the value of regional climate modelling using palaeoclimate simulations, Geophys. Res. Lett., 46, 12464-12475, https://doi.org/10.1029/2019GL085127, 2019.

Bartlein, P. J., Harrison, S. P., Brewer, S., Connor, S., Davis, B.A. S., Gajewski, K., Guiot, J., Harrison-Prentice, T. I., Henderson, A., Peyron, O., Prentice, I. C., Scholze, M., Seppä, H., Shuman, B., Sugita, S., Thompson, R. S., Viau, A. E., Williams, J., and $\mathrm{Wu}, \mathrm{H}$.: Pollen-based continental climate reconstructions at 6 and 21 ka: A global synthesis, Clim. Dynam., 37, 775-802, https://doi.org/10.1007/s00382-010-0904-1, 2011.

Beghin, P., Charbit, S., Kageyama, M., Combourieu-Nebout, N., Hatté, C., Dumas, C., and Peterschmitt, J.-Y.: What drives LGM precipitation over the western Mediterranean? A study focused on the Iberian Peninsula and northern Morocco, Clim. Dynam., 46, 2611-2631, https://doi.org/10.1007/s00382-015-27200, 2016.

Bengtsson, L., Hodges, K. I., and Keenlyside, N.: Will extratropical storms intensify in a warmer climate?, J. Climate, 22, 22762301, https://doi.org/10.1175/2008JCLI2678.1, 2009.

Born, K., Ludwig, P., and Pinto, J. G.: Wind gust estimation for Mid-European winter storms: Towards a probabilistic view, Tellus A, 64, 17471, https://doi.org/10.3402/tellusa.v64i0.17471, 2012.

Braconnot, P., Harrison, S. P., Kageyama, M., Bartlein, P. J., Masson-Delmotte, V., Abe-Ouchi, A., Otto-Bliesner, B., and Zhao, Y.: Evaluation of climate models using palaeoclimatic data, Nat. Clim. Change, 2, 417-424, https://doi.org/10.1038/nclimate1456, 2012.

Catto, J. L., Shaffrey, L. C., and Hodges, K. I.: Can climate models capture the structure of extratropical cyclones?, J. Climate, 23 1621-1635, https://doi.org/10.1175/2009JCLI3318.1, 2010.

Catto, J. L., Ackerley, D., Booth, J., Champion, A., Colle, B., Pfahl, S., Pinto, J. G., Quinting, J., and Seiler, C.: The Future of Extratropical Cyclones, Curr. Clim. Change Rep., 5, 407-420, https://doi.org/10.1007/s40641-019-00149-4, 2019.

Chang, E. K. M., Lee, S., and Swanson, K. L.: Storm track dynamics, J. Climate, 15, 2163-2183, https://doi.org/10.1175/1520 0442(2002)015<02163:STD>2.0.CO;2, 2002.

Clark, P. U., Dyke, A. S., Shakun, J. D., Carlson, A. E., Clark, J., Wohlfarth, B., Mitrovica, J. X., Hostetler, S. W., and McCabe, A. M.: The Last Glacial Maximum, Science, 325, 710 714, https://doi.org/10.1126/science.1172873, 2009.

Cleator, S. F., Harrison, S. P., Nichols, N. K., Prentice, I. C., and Roulstone, I.: A new multi-variable benchmark for Last 
Glacial Maximum climate simulations, Clim. Past Discuss., https://doi.org/10.5194/cp-2019-55, in review, 2019.

CLIMAP Project Members: The last interglacial ocean, Quaternary Res., 2, 123-224, https://doi.org/10.1016/0033-5894(84)90098X, 1984

Dacre, H. F., Hawcroft, M. K., Stringer, M. A., and Hodges, K. I.: An extratropical cyclone database: A tool for illustrating cyclone structure and evolution characteristics, B. Am. Meteorol. Soc., 93, 1497-1502, https://doi.org/10.1175/BAMS-D-1100164.1, 2012.

Donohoe, A. and Battisti, D. S.: Causes of Reduced North Atlantic Storm Activity in a CAM3 Simulation of the Last Glacial Maximum, J. Climate, 22, 4793-4808, https://doi.org/10.1175/2009JCLI2776.1, 2009.

Ferrier, B. S., Tao, W.-K., and Simpson, J.: A double-moment multiple-phase four-class bulk ice scheme. Part II: Simulations of convective storms in different large-scale environments and comparisons with other bulk parameterizations, J. Atmos. Sci., 52, 8, 1001-1033, https://doi.org/10.1175/15200469(1995)052<1001:ADMMPF>2.0.CO;2, 1995.

Fitzsimmons, K. E., Markovic, S. B., and Hambach, U.: Pleistocene environmental dynamics recorded in the loess of the middle and lower Danube basin, Quaternary Sci. Rev., 41, 104-118, https://doi.org/10.1016/j.quascirev.2012.03.002, 2012.

Hawcroft, M. K., Shaffrey, L. C., Hodges, K. I., and Dacre, H. F.: How much Northern Hemisphere precipitation is associated with extratropical cyclones?, Geophys. Res. Lett., 39, L24809, https://doi.org/10.1029/2012GL053866, 2012.

Hawcroft, M. K., Shaffrey, L. C., Hodges, K. I., and Dacre, H. F.: Can climate models represent the precipitation associated with extratropical cyclones?, Clim. Dynam., 47, 679-695, https://doi.org/10.1007/s00382-015-2863-z, 2016.

Harrison, S. P., Bartlein, P. J., Izumi, K., Li, G., Annan, J., Hargreaves, J., Braconnot, P., and Kageyama, M.: Evaluation of CMIP5 palaeo-simulations to improve climate projections, Nat. Clim. Change, 5, 735-743, https://doi.org/10.1038/nclimate2649, 2015.

Harrison, S. P., Bartlein, P. J., and Prentice, I. C.: What have we learnt from palaeoclimate simulations?, J. Quaternary Sci., 31, 363-385, https://doi.org/10.1002/jqs.2842, 2016.

Hewson, T. D. and Neu U.: Cyclones, windstorms and the IMILAST project, Tellus A, 67, 27128, https://doi.org/10.3402/tellusa.v67.27128, 2015.

Hofer, D., Raible, C. C., Dehnert, A., and Kuhlemann, J.: The impact of different glacial boundary conditions on atmospheric dynamics and precipitation in the North Atlantic region, Clim. Past, 8, 935-949, https://doi.org/10.5194/cp-8-935-2012, 2012.

Hoskins B. J. and Hodges K. I.: New perspectives on the Northern Hemisphere winter storm tracks, J. Atmos. Sci., 59, 1041-1061, https://doi.org/10.1175/15200469(2002)059<1041:NPOTNH>2.0.CO;2, 1990.

Hoskins, B. J. and Valdes, P. J.: On the existence of storm tracks, J. Atmos. Sci., 47, 1854-1864, https://doi.org/10.1175/15200469(1990)047<1854:OTEOST>2.0.CO;2, 1990.

Iacono, M. J., Delamere, J. S., Mlawer, E. J., Shephard, M. W., Clough, S. A., and Collins W. D.: Radiative forcing by long-lived greenhouse gases: Calculations with the AER radiative transfer models, J. Geophys. Res., 113, D13103, https://doi.org/10.1029/2008JD009944, 2008.
Ishizuka, M., Mikami, M., Leys, J., Yamada, Y., Heidenreich, S., Shao, Y., and McTainsh, G. H.: Effects of soil moisture and dried raindroplet crust on saltation and dust emission, J. Geophys. Res., 113, D24212, https://doi.org/10.1029/2008JD009955, 2008.

Janjić, Z. I.: The Step-Mountain Eta Coordinate Model: Further Developments of the Convection, Viscous Sublayer, and Turbulence Closure Schemes, Mon. Weather Rev., 122, 927-945, https://doi.org/10.1175/15200493(1994)122<0927:TSMECM>2.0.CO;2, 1994.

Jungclaus, J. H., Fischer, N., Haak, H., Lohmann, K, Marotzke, J., Matei, D., Mikolajewicz, U., Notz, D., and von Storch, J.S.: Characteristics of the ocean simulations in the Max Planck Institute Ocean Model (MPIOM) the ocean component of the MPI-Earth system model, J. Adv. Model. Earth Sy., 5, 422-446, https://doi.org/10.1002/jame.20023, 2013.

Kageyama, M., Valdes, P. J., Ramstein, G., Hewitt, C., and Wyputta, U.: Northern Hemisphere storm tracks in present day and Last Glacial Maximum climate simulations: A comparison of the European PMIP models, J. Climate, 12, 742-760, https://doi.org/10.1175/15200442(1999)012<0742:NHSTIP>2.0.CO;2, 1999.

Kageyama, M., Albani, S., Braconnot, P., Harrison, S. P., Hopcroft, P. O., Ivanovic, R. F., Lambert, F., Marti, O., Peltier, W. R., Peterschmitt, J.-Y., Roche, D. M., Tarasov, L., Zhang, X., Brady, E. C., Haywood, A. M., LeGrande, A. N., Lunt, D. J., Mahowald, N. M., Mikolajewicz, U., Nisancioglu, K. H., Otto-Bliesner, B. L., Renssen, H., Tomas, R. A., Zhang, Q., Abe-Ouchi, A., Bartlein, P. J., Cao, J., Li, Q., Lohmann, G., Ohgaito, R., Shi, X., Volodin, E., Yoshida, K., Zhang, X., and Zheng, W.: The PMIP4 contribution to CMIP6 - Part 4: Scientific objectives and experimental design of the PMIP4-CMIP6 Last Glacial Maximum experiments and PMIP4 sensitivity experiments, Geosci. Model Dev., 10, 4035-4055, https://doi.org/10.5194/gmd-10-4035-2017, 2017.

Kageyama, M., Braconnot, P., Harrison, S. P., Haywood, A. M., Jungclaus, J. H., Otto-Bliesner, B. L., Peterschmitt, J.-Y., AbeOuchi, A., Albani, S., Bartlein, P. J., Brierley, C., Crucifix, M., Dolan, A., Fernandez-Donado, L., Fischer, H., Hopcroft, P. O., Ivanovic, R. F., Lambert, F., Lunt, D. J., Mahowald, N. M., Peltier, W. R., Phipps, S. J., Roche, D. M., Schmidt, G. A., Tarasov, L., Valdes, P. J., Zhang, Q., and Zhou, T.: The PMIP4 contribution to CMIP6 - Part 1: Overview and overarching analysis plan, Geosci. Model Dev., 11, 1033-1057, https://doi.org/10.5194/gmd-11-1033-2018, 2018.

Kalnay, E., Kanamitsu, M., Kistler, R., Collins, W., Deaven, D., Gandin, L., Iredell, M., Saha, S., White, G., Woollen, J., Zhu, Y., Chelliah, M., Ebisuzaki, W., Higgins, W., Janowiak, J., Mo, K. C., Ropelewski, C., Wang, J., Leetmaa, A., Reynolds, R., Jenne, R., and Joseph, D.: The NCEP/NCAR 40-Year Reanalysis Project, B. Am. Meteorol. Soc., 77, 437-472, https://doi.org/10.1175/15200477(1996)077<0437:TNYRP>2.0.CO;2, 1996.

Laîné, A., Kageyama, M., Salas-Mélia, D., Voldoire, A., Rivière, G., Ramstein, G., Planton, S., Tyteca, S., and Peterschmitt, J.Y.: Northern Hemisphere storm tracks during the Last Glacial Maximum in the PMIP2 ocean-atmosphere coupled models: Energetic study, seasonal cycle, precipitation, Clim. Dynam., 32, 593-614, https://doi.org/10.1007/s00382-008-0391-9, 2009. 
Lambeck, K. and Chappell, J.: Sea level change through the last glacial cycle, Science, 292, 679-686, https://doi.org/10.1126/science.1059549, 2001.

Lambeck, K., Yokoyama, Y., and Purcell, A.: Into and out of the Last glacial Maximum sea level change during Oxygen Isotope Stages 3-2, Quaternary Sci. Rev., 21, 343-360, https://doi.org/10.1016/S0277-3791(01)00071-3, 2002.

Löfverström, M.: A dynamic link between high-intensity precipitation events in southwestern North America and Europe at the Last Glacial Maximum, Earth Planet. Sc. Lett., 534, 116081, https://doi.org/10.1016/j.epsl.2020.116081, 2020.

Löfverström, M., Caballero, R., Nilsson, J., and Kleman, J.: Evolution of the large-scale atmospheric circulation in response to changing ice sheets over the last glacial cycle, Clim. Past, 10, 1453-1471, https://doi.org/10.5194/cp-10-1453-2014, 2014.

Löfverström, M., Caballero, R., Nilsson, J., and Messori, G.: Stationary wave reflection as a mechanism for zonalising Atlantic winter jet at the LGM, J. Atmos. Sci., 73, 3329-3342, https://doi.org/10.1175/JAS-D-15-0295.1, 2016.

Ludwig, P., Pinto, J. G., Hoepp, S. A., Fink, A. H., and Gray, S. L.: Secondary cyclogenesis along an occluded front leading to damaging wind gusts: windstorm Kyrill, January 2007, Mon. Weather Rev., 143, 1417-1437, https://doi.org/10.1175/MWRD-14-00304.1, 2015.

Ludwig, P., Schaffernicht, E. J., Shao, Y., and Pinto, J. G.: Regional atmospheric circulation over Europe during the Last Glacial Maximum and its links to precipitation, J. Geophys. Res.-Atmos., 121, 2130-2145, https://doi.org/10.1002/2015JD024444, 2016.

Ludwig, P., Pinto, J. G., Raible, C. C., and Shao,Y.: Impacts of surface boundary conditions on regional climate model simulations of European climate during the Last Glacial Maximum, Geophys. Res. Lett., 44, 5086-5095, https://doi.org/10.1002/2017GL073622, 2017.

Ludwig, P., Shao, Y., Kehl, M., and Weniger, G.-C.: The Last Glacial Maximum and Heinrich event I on the Iberian Peninsula: A regional climate modelling study for understanding human settlement patterns, Global Planet. Change, 170, 34-47, https://doi.org/10.1016/j.gloplacha.2018.08.006, 2018.

Ludwig, P., Gómez-Navarro, J. J., Pinto, J. G., Raible, C. C., Wagner, S., and Zorita, E.: Perspectives of regional paleoclimate modeling, Ann. NY. Acad. Sci., 1436, 54-69, https://doi.org/10.1111/nyas.13865, 2019.

Luetscher, M., Boch, R., Sodemann, H., Spötl, C., Cheng, H., Edwards, R.L., Frisia, S., Hof, F., and Muller, W.: North Atlantic storm track changes during the Last Glacial Maximum recorded by Alpine speleothems, Nat. Commun., 6, 6344, https://doi.org/10.1038/ncomms7344, 2015.

Maher, B. A., Prospero, J. M., Mackie, D., Gaiero, D., Hesse, P. P., and Balkanski, Y.: Global connections between aeolian dust, climate and ocean biogeochemistry at the present day and at the last glacial maximum, Earth-Sci. Rev., 99, 61-97, https://doi.org/10.1016/j.earscirev.2009.12.001, 2010.

Merz, N., Raible, C. C., and Woollings, T.: North Atlantic eddy-driven jet in interglacial and glacial winter climates, J. Climate, 28, 3977-3997, https://doi.org/10.1175/JCLI-D-14$00525.1,2015$.

Moreno, A., Svensson, A., Brooks, S. J., Connor, S., Engels, S., Fletcher, W., Genty, D., Heiri, O., Labuhn, I., Perşoiu,
A., Peyron, O., Sadori, L., Valero-Garcés, B., Wulf, S., and Zanchetta, G.: A compilation of western European terrestrial records $60-8 \mathrm{kaBP}$ : towards an understanding of latitudinal climatic gradients, Quaternary Sci. Rev. 106, 167-185, https://doi.org/10.1016/j.quascirev.2014.06.030, 2014.

Murray, R. J. and Simmonds, I.: A numerical scheme for tracking cyclone centres from digital data. Part I: Development and operation of the scheme, Aust. Meteorol. Mag., 39, 155-166, 1991.

Neu, U., Akperov, M. G., Bellenbaum, N., Benestad, R., Blender, R., Caballero, R., Cocozza, A., Dacre, H. F., Feng, Y., Fraedrich, K., Grieger, J., Gulev, S., Hanley, J., Hewson, T., Inatsu, M., Keay, K., Kew, S. F., Kindem, I., Leckebusch, G. C., Liberato, M. L. R., Lionell, P., Mokhov, I. I., Pinto, J. G., Raible, C. C., Reale, M., Rudevaia, I., Schuster, M., Simmonds, I., Sinclair, M., Sprenger, M., Tilinina, N. D., Trigo, I. F., Ulbrich, S., Ulbrich, U., Wang, X. L., and Wernli, H.: IMILAST: A community effort to intercompare extratropical cyclone detection and tracking algorithms, B. Am. Meteorol. Soc., 94, 529-547, https://doi.org/10.1175/BAMS-D-11-00154.1, 2013.

Peltier, W. R., Argus, D. F., and Drummond, R.: Space geodesy constrains ice age terminal deglaciation: The global ICE-6G_C (VM5a) model, J. Geophys. Res.-Sol. Ea., 119, 450-487, https://doi.org/10.1002/2014JB011176, 2015.

Pfahl, S. and Wernli, H.: Quantifying the Relevance of Cyclones for Precipitation Extremes, J. Climate, 25, 6770-6780, https://doi.org/10.1175/JCLI-D-11-00705.1, 2012.

Pfahl, S., O'Gorman, P., and Singh, M.S.: Extratropical cyclones in idealized simulations of changed climates, J. Climate, 28, 93739392, https://doi.org/10.1175/JCLI-D-14-00816.1, 2015.

Pinto, J. G., Spangehl, T., Ulbrich, U., and Speth, P.: Sensitivities of a cyclone detection and tracking algorithm: individual tracks and climatology, Meteorol. Z., 14, 823-838, https://doi.org/10.1127/0941-2948/2005/0068, 2005.

Pinto, J. G., Ulbrich, U., Leckebusch, G. C., Spangehl, T., Reyers, M., and Zacharias, S.: Changes in storm track and cyclone activity in three SRES ensemble experiments with the ECHAM5/MPI-OM1 GCM, Clim. Dynam., 29, 195-210, https://doi.org/10.1007/s00382-007-0230-4, 2007.

Pinto, J. G., Zacharias, S., Fink, A. H., Leckebusch, G. C., and Ulbrich, U.: Factors contributing to the development of extreme North Atlantic cyclones and their relationship with the NAO, Clim. Dynam., 32, 711-737, https://doi.org/10.1007/s00382008-0396-4, 2009.

Prospero, J. M., Ginoux, P., Torres, O., Nicholson, S. E., and Gill, T. E.: Environmental characterization of global sources of atmospheric soil dust identified with the Nimbus 7 Total Ozone Mapping Spectrometer (TOMS) Absorbing Aerosol Product, Rev. Geophys., 40, 1002, https://doi.org/10.1029/2000RG000095, 2002.

Raible, C. C., Messmer, M., Lehner, F., Stocker, T. F., and Blender, R.: Extratropical cyclone statistics during the last millennium and the 21st century, Clim. Past, 14, 1499-1514, https://doi.org/10.5194/cp-14-1499-2018, 2018.

Ray, N. and Adams, J. M.: A GIS-based Vegetation Map of the World at the Last Glacial Maximum (25,000-15,000 BP), Internet Archaeology, 11, 1-44, https://doi.org/10.11141/ia.11.2, 2001.

Riviére, G., Lainé, A., Lapeyre, G., Salas-Mélia, D., and Kageyama, M.: Links between Rossby wave breaking and the North At- 
lantic Oscillation-Arctic Oscillation in present day and Last Glacial Maximum climate simulations, J. Climate, 23, 29873008, https://doi.org/10.1175/2010JCLI3372.1, 2010.

Rivière, G., Berthou, S., Lapeyre, G., and Kageyama, M.: On the Reduced North Atlantic Storminess during the Last Glacial Period: The Role of Topography in Shaping Synoptic Eddies, J. Climate, 31, 1637-1652, https://doi.org/10.1175/JCLI-D-170247.1, 2018.

Rudeva, I. and Gulev S. K.: Composite Analysis of North Atlantic Extratropical Cyclones in NCEP-NCAR Reanalysis Data, Mon. Weather Rev., 139, 1419-1446, https://doi.org/10.1175/2010MWR3294.1, 2011.

Schaffernicht, E. J., Ludwig, P., and Shao, Y.: Linkage between Dust Cycle and Loess of the Last Glacial Maximum in Europe, Atmos. Chem. Phys. Discuss., https://doi.org/10.5194/acp-2019693, in review, 2019.

Schulz, J.-P.: Revision of the turbulent gust diagnostics in the COSMO model, COSMO Newsletter 8, 17-22, available at: http: //www.cosmo-model.org (last access: 28 March 2020), 2008.

Schulz, J.-P. and Heise, E.: A new scheme for diagnosing near-surface convective gusts, COSMO Newsletter 3, 221225, available at: http://www.cosmo-model.org (last access: 28 March 2020), 2003.

Shao, Y., Wyrwoll, K.-H., Chappell, A., Huang, J., Lin, Z., McTainsh, G. H., Mikami, M., Tanaka, T. Y., Wang, X., and Yoon, S.: Dust cycle: An emerging core theme in Earth system science, Aeolian Res., 2, 181-204, 2011.

Shao, Y., Anhäuser, A., Ludwig, P., Schlüter, P., and Williams, E.: Statistical reconstruction of global vegetation for the last glacial maximum, Global Planet. Change, 168, 67-77, https://doi.org/10.1016/j.gloplacha.2018.06.002, 2018.

Sima, A., Kageyama, M., Rousseau, D.-D., Ramstein, G., Balkanski, Y., Antoine, P., and Hatté, C.: Modeling dust emission response to North Atlantic millennial-scale climate variations from the perspective of East European MIS 3 loess deposits, Climate of the Past, 9, 1385-1402, https://doi.org/10.5194/cp-91385-2013, 2013.

Sinclair, V. A., Rantanen, M., Haapanala, P., Räisänen, J., and Järvinen, H.: The characteristics and structure of extra-tropical cyclones in a warmer climate, Weather Clim. Dynam. 1, 1-25, https://doi.org/10.5194/wcd-1-1-2020, 2020.

Skamarock, W.C., Klemp, J. B., Dudhia, J., Gill, D. O., Barker, D. M., Duda, M. G., Huang, X.-Y., Wang, W., and Powers, J. G.: A description of the advanced research WRF version 3, NCAR Tech. Note NCAR/TN-475+STR, 113 pp., https://doi.org/10.5065/D68S4MVH, 2008.

Stevens, B., Giorgetta, M., Esch, M., Mauritsen, T., Crueger, T.,Rast, S., Salzmann, M., Schmidt, H., Bader, J., Block, K.,Brokopf, R., Fast, I., Kinne, S., Kornblueh, L., Lohmann, U., Pincus, R., Reichler, T., and Roeckner, E.: Atmospheric component of the MPI-M Earth system model: ECHAM6, J. Adv. Model. Earth Sy., 5, 146-172, https://doi.org/10.1002/jame.20015, 2013.
Tarasov, L. and Peltier, W. R.: Greenland glacial history and local geodynamic consequences, Geophys. J. Int., 150, 198-229, https://doi.org/10.1046/j.1365-246X.2002.01702.x, 2002.

Tarasov, L. and Peltier, W. R.: Greenland glacial history, borehole constraints, and Eemian extent, J. Geophys. Res., 108, 2143, https://doi.org/10.1029/2001JB001731, 2003.

Tewari, M., Chen, F., Wang, W., Dudhia, J., LeMone, M. A., Mitchell, K., Ek, M., Gayno, G., Wegiel J., and Cuenca, R. H.: Implementation and verification of the unified NOAH land surface model in the WRF model, 20th conference on weather analysis and forecasting/16th conference on numerical weather prediction, 12-16 January 2004, Seattle, Washington, 11-15, 2004.

Ugan, A. and Byers, D.: Geographic and temporal trends in proboscidean and human radiocarbon histories during the late Pleistocene, Quaternary Sci. Rev., 26, 3058-3080, https://doi.org/10.1016/j.quascirev.2007.06.024, 2007.

Újvári, G., Stevens, T., Molnár, M., Demény, A., Lambert, F., Varga, G., Jull, A. J. T., Páll-Gergely, B., Buylaert, J. P., and Kovács, J.: Coupled European and Greenland last glacial dust activity driven by North Atlantic climate, P. Natl. Acad. Sci. USA, 114, E10632-E10638, https://doi.org/10.1073/pnas.1712651114, 2017.

Ulbrich, U., Leckebusch, G. C., and Pinto, J. G.: Extra-tropical cyclones in the present and future climate: A review, Theor. Appl. Climatol., 96, 117-131, https://doi.org/10.1007/s00704008-0083-8, 2009.

Wang, N., Jiang, D., and Lang, X.: Northern Westerlies during the Last Glacial Maximum: results from CMIP5 simulations, J. Climate, 31, 1135-1153, https://doi.org/10.1175/JCLI-D-170314.1, 2018.

Wernli, H., Dirren, S., Liniger, M. A., and Zillig, M.: Dynamical aspects of the life cycle of the winter storm "Lothar" (2426 December 1999), Q. J. Roy. Meteor. Soc., 128, 405-429, https://doi.org/10.1256/003590002321042036, 2002.

Zhang, C., Wang, Y., and Hamilton, K.: Improved Representation of Boundary Layer Clouds over the Southeast Pacific in ARW-WRF Using a Modified Tiedtke Cumulus Parameterization Scheme, Mon. Weather Rev., 139, 3489-3513, https://doi.org/10.1175/MWR-D-10-05091.1, 2011. 